Irish Math. Soc. Bulletin

Number 85, Summer 2020, 3-15

ISSN 0791-5578

\title{
Martin Gardiner: the first Irish-Australian mathematician
}

\author{
GRAEME L. COHEN
}

\begin{abstract}
Martin Gardiner was one of the first students enrolled in Queen's College, Galway, in 1850. He performed exceptionally well but ended his studies in civil engineering after just two years. While there, he developed his own set of correspondents, such as Richard Townsend in Trinity College, Dublin, through which he maintained a comprehensive knowledge of current developments in geometry. By 1857, he was in Melbourne, Australia, and was soon promoting himself as more capable than any local mathematician. He took surveying positions around the country, never for more than five years at a time, and everywhere he lived advertised himself as a private tutor, or as conducting a school for mathematicians and engineers. None was successful. Gardiner had over twenty publications in the proceedings of the Royal Societies of Victoria and New South Wales, as well as a few in leading English journals.
\end{abstract}

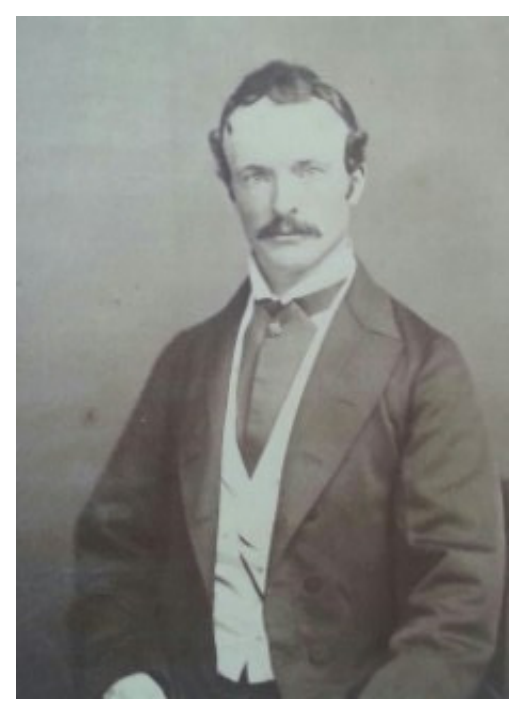

Martin Gardiner, from his paper The three sections ....

\section{INTRODUCTION}

Until the appearance of my book, Counting Australia In (Cohen [2]), and more recently my bibliography of Australian mathematics (Cohen [3]), very little had been written about the surveyor, mathematician and perennial combatant, Martin Gardiner. The online Encyclopedia of Australian Science says little more than that he "was a mathematician who specialised in geometry," and refers only to his time in Victoria (see http://www.eoas.info/biogs/P001569b.htm). In fact, Gardiner, born in Ireland around 1833, was a surveyor who worked in all states of Australia except Tasmania, rarely holding a job for more than five years. He was aggressive and insulting towards

2010 Mathematics Subject Classification. 01-XX.

Key words and phrases. Galway, Gardiner, Geometry, Surveying, Mathematics.

Received on 5-3-2020. 
his colleagues, highly critical of his superiors, a bankrupt, and violent towards his wife. There is some evidence that he falsified his academic qualifications.

Yet he was indeed a capable and knowledgable mathematician, apparently largely selftaught, and well aware of the current research in his field, with twenty or so publications to his credit including some in the best English journals. The full list of his publications, as far as they are known to me, is given in the Appendix. In Counting Australia In (p. 75), I wrote: "Gardiner's work is generally very detailed and difficult to fathom, and none of it has lasted." But in his day he received lavish praise from some of the most highly regarded English mathematicians.

This article is based in large measure on newspaper reports of Royal Society and other meetings and reports of New South Wales parliamentary proceedings, on government Gazette notices, on newspaper advertisements, and on letters to the editors of dozens of newspapers. Gardiner was a prolific letter writer, always ready to criticise the colonists among whom he lived and worked. Other sources include journal notices and a number of birth, death and marriage certificates.

Over the past five years or so, there has been a lively email discussion ascertaining various facets of Gardiner's life and work. I very much appreciate the efforts and advice in this period of professors Alan Atkinson, Colm Mulcahy and James Tattersall.

\section{First, Melbourne}

Martin Gardiner arrived in Melbourne on 9 December 1856 aboard the Royal Charter with his wife, maiden name Bridget Mary Maguire, two-year old son Charles Napoleon and infant daughter Margaret. Just a few months later, on 17 March 1857, the baby Margaret died from dysentery, aged two years and two months; and a month after that, on 20 April, another child, James, was born. The Royal Charter's passenger list gives Martin's age on board as 24 and Bridget's as 18, but the latter could hardly be correct. Indeed, James' birth certificate states that Bridget was then aged 22, and was born in Limerick, Ireland. Gardiner's age is given as 25 and his birthplace as Galway, Ireland (but evidence below will suggest the more likely possibility that he was born in Dublin). The birth certificate states also that Martin and Bridget had married on 7 December 1852 at Sherbrook, near Montréal, Canada.

Details of Gardiner's education are sketchy. Alan Atkinson found that The Dublin Evening Post reported on 31 December 1850 that a science scholarship for a Martin Gardiner in the Faculty of Arts at Queens College, Galway, had been "granted" on the 23rd; and the Dublin Advocate reported the same on 1 January 1851. Colm Mulcahy passed on photographs of the handwritten log from the Registrar's Office at the college, which show a Martin Gardiner from "Dublin School" admitted as "A Scholar in Engineering" on 7 January 1850 for the session 1849-50, and being "A Scholar 1st Year Arts" for 1850-1851. ${ }^{1}$ The details for those two years are confirmed by entries in the Calendar for Queen's College, Galway, for the year 1899 (available online). There are no further mentions and, in particular, the Calendar does not include Gardiner among its list of all graduates of the college up to 1898. So Gardiner, who would very often sign himself as "Martin Gardiner, C.E., Scholar of Queen's College, Galway", does not appear from this to have completed a full course of study there. (See Mitchell [10] for a description of the College's early years.)

However, he brought with him to Australia a certificate from the college, dated September 1852 and stating: "We ... do hereby certify that Mr. Martin Gardiner has diligently pursued the Course of Study prescribed in the Queen's University in Ireland, and is duly qualified to act as Assistant-Civil-Engineer." Alongside that certificate is another, "to Certify that at an Examination held on the 12th day of June, 1851, Mr.

\footnotetext{
${ }^{1}$ The photographs were obtained by Professor Ted Hurley, there. I am most grateful.
} 
Martin Gardiner has been awarded a Prize of First Rank for Proficiency in Natural Philosophy during the second year of his academic course." ${ }^{2}$ There is no evidence that he undertook further tertiary studies anywhere else.

Gardiner, possibly with Bridget, left for Canada soon after his time at Queen's College. The County Galway Surname List ${ }^{3}$ confirms this in very brief terms. The list says of Gardiner no more than: "born about 1832 emigrated to Canada by about 1850". In Canada, Gardiner worked for the Grand Trunk Railway, and that is about all that is known of his time there.

In contrast to her husband, Bridget may have been illiterate: on James' birth certificate, she signed with her mark, "X".

Within a year of his arrival in Australia, Gardiner issued a challenge: "To the Mathematicians of Australia. - $£ 10$ for any Person who shall (before the 1st of January, 1858,) present to the Public Library of Melbourne ORIGINAL GEOMETRICAL PAPERS to equal or excel those which I shall have contributed. - Martin Gardiner, C.E." ${ }^{4}$ Just about all of his contributions to newspapers, over 40 years and from five Australian states, exhibited the same self-promoting arrogance and deprecating of the local colonists.

On 28 May 1859, he gave a public lecture entitled "The necessity of having the Mathematics and Applied Mechanics occupy a more prominent place in public instruction" 5 and soon after, he was advertised as giving regular lectures for the Mechanics Institution: classes in "Mathematics and Mechanical Philosophy ... every Tuesday and Saturday Evening, 7 to 9 o'clock. Two guineas for the session, and no extra charges for instructions in calculus, descriptive geometry, framing, skew bridges, \&c." ${ }^{6}$ These classes did not eventuate, as "those who were so eager to join the classes have not been forthcoming." 7 This was the first of many instances of failed attempts to establish himself as a teacher.

Gardiner was elected a member of the Philosophical Institute of Victoria in June 1859. He had a paper, "Improvements in Fundamental Ideas and Elementary Theorems of Geometry", 8 in Volume 4 of the Transactions of the Institute published that year. Although this, his first paper, is dated 1859, he had earlier presented a bound volume of three papers in 40 pages entitled Geometrical Papers to the Melbourne Public Library. These no doubt formed the basis for his challenge, two years before. He wrote in his introduction to these Papers that he had endeavoured to bring the work to the notice of William Parkinson Wilson (1826?-1874), professor of mathematics in the recently established University of Melbourne, but, as I wrote in Counting Australia In (p. 75), "in the manner of countless academics when similarly approached, "the learned proffessor [sic] did not wish to enter into the details of my methods'."

At the meeting of the Philosophical Institute on 30 November 1859, Gardiner read a paper "Hints for Field Practice, in the Laying-out of Compound-circular and Parabolic Railway Curves". The Institute was transformed into the Royal Society of Victoria in the following year, and Gardiner stood unsuccessfully for election to its council in April.

\footnotetext{
${ }^{2}$ The certificates are among the collected correspondence of Sir Henry Parkes, Volume 27, call no. A897 (State Library of NSW), pp. 236-240.

${ }^{3}$ www.rootsweb.ancestry.com/ irlgalway/galway.htm.

${ }^{4}$ The Argus, 19 October 1857.

${ }^{5}$ The Age, 25 May 1859. Many newspaper advertisements were repeated in the following days. Generally, only the first occurrence is recorded here.

${ }^{6}$ The Age, 2 June 1859.

${ }^{7}$ The Argus, 30 June 1859.

8 "Read before the Institute 13th July and 3rd August, 1859."

${ }^{9}$ Before his appointment to the chair in Melbourne, Wilson had been the foundation professor of mathematics in Queen's College, Belfast.
} 
He read a paper to its meeting on 4 June 1860 ("Analogous Solutions to the Section of Ratio, Section of Space, and Determinate Section of Apollonius, with their Generating Problems"), and on 30 September 1861 his paper "A few observations on the tangencies of Apollonius" was "laid upon the table".

\section{SYDNEY}

In August 1860 Gardiner, with Bridget and their two surviving children, moved to Sydney with the expectation that he would obtain employment in the department of railways. Just five months later, on 23 January, Bridget died of a lung disease, aged 27. According to the death certificate, the burial was witnessed by a young friend, Emma Guile, who was to become Martin's second wife soon after, on 13 August. Their marriage certificate gives Emma's age as 18 at the time and her birthplace as London. Martin's birthplace is given as Dublin, not Galway as stated above, and his parents are stated as William ("a Gentleman") and Mary. On 12 June 1862, Emma gave birth to a son, Martin. There would be two more children: daughters, Emma on 18 September 1864 and Mary Louisa in Newcastle, New South Wales, on 25 October 1867. This marriage ended in violence by Gardiner against Emma, then desertion and finally divorce.

Gardiner was exceptionally proud of the paper he presented to the Philosophical Society of New South Wales on 9 July 1862. It was titled "Improvements in geometrical science, with their applications in solutions to celebrated problems, and in the investigations of new Porisms." ${ }^{10}$ Two months earlier, he had written to the editor of the Sydney critical newspaper, the Empire, "As I have determined on publishing a model solution to a celebrated geometrical problem, I hope you will be so kind as to insert its history in your philanthropic journal, and be a benefactor to pure science in this colony, where the highest intellectual ambition of the rising generation is almost entirely directed to what I consider the useless, inglorious, art of 'cricket-batting.'"

The problem in its simplest form is: To inscribe a triangle in a given circle, such that its sides (produced if necessary) shall pass through three given points. The Empire did indeed publish (in almost 1300 words) Gardiner's history of the Cramer-Castillon problem, as it is now known. Much of this history was taken, with very similar wording in some parts, from a paper by Thomas Davies [5] that had appeared a dozen years before. Gardiner acknowledged Davies' paper in a more detailed history of the "celebrated problem" at the end of the third part of his "Geometrical Researches" (Appendix (e)), where his complete analysis was given. Generalisations of the Cramer-Castillon problem were the subject of a number of Gardiner's papers, and undoubtedly constituted his best work in mathematics.

Regarding the presentation to the Philosophical Society, the Herald (10 July 1862) wrote, "Last night, the monthly meeting of the Philosophical Society of New South Wales was held in the hall of the Australian Library ... Two papers were read - the first by Mr. Martin Gardiner, C.E., ... Mr. G. introduced supplementary ideas concerning the modes of formation of lines in respect of points, and of surfaces in respect to lines and points; and, although the subject was of a very abstruse character, he succeeded in rendering it, by the aid of diagrams, somewhat interesting ..."

In a letter to the Empire, on 27 January 1863, in which he signs himself as working for the "Railway Department", Gardiner paid tribute to "the newly appointed Chief Justice of Queensland ... [who] is well known as a very eminent mathematician." Not named by Gardiner in the letter, this was Sir James Cockle (1819-1895). (See Bennett [1], Deakin [6].) In 1867 Gardiner read a paper of Cockle's to a meeting of the Royal

\footnotetext{
${ }^{10}$ From Wikipedia: "A porism is a mathematical proposition or corollary. In particular, the term porism has been used to refer to a direct result of a proof, analogous to how a corollary refers to a direct result of a theorem."
} 
Society of New South Wales. In 1870, Cockle supported Gardiner in his unsuccessful application for the chair of mathematics in the newly established University of Otago, New Zealand (to be described in detail below).

Gardiner presented a paper to a meeting of the Philosophical Society of New South Wales on 17 June 1863 ("Complete Solution to a Celebrated Problem"). Another paper was scheduled for presentation at the next monthly meeting of the Society on 8 July ("The correct scientific method of forming railway curves and railways, with an exposition of the injurious effects of the system adopted in this colony"), but, perhaps because of the controversial nature of the paper, it was deferred to the subsequent meeting on 12 August. Gardiner wrote to the editor of the Empire on 14 August, asking that "in order to ... advance the interests of the colony," the paper be printed in the newspaper in full; and this was done.

Gardiner read a paper, "On improved analytical geometry," to a meeting of the Royal Society of New South Wales on 17 August $1864 .^{11}$

In an announcement in The Sydney Morning Herald on 6 March 1865, "Mr. Sheridan Moore, Licensed Tutor of the University", informed "undergraduates and others" that Gardiner was to "take charge of all his advanced Mathematical Classes." Joseph Sheridan Moore was a prolific local poet and essayist. He was involved in a number of educational ventures (as was Gardiner), none of which succeeded. An Irishman who migrated to Sydney in 1847, Moore "was esteemed by some but condemned as a charlatan by the native-born members [of his literary group] who distrusted him" (Glass [7]).

\section{NeWCASTle}

By the end of July 1865, Gardiner and family had moved to Newcastle, north of Sydney, where Gardiner had obtained the position of City Surveyor. As usual, wherever he went, he was keen to promote himself as a teacher. In the Newcastle Chronicle on 23 September 1865, he advertised his services as follows. "Mathematics, Surveying, Engineering \&c, taught to Gentlemen who wish to undergo Civil Service Examinations, or to obtain Certificates of Qualification as Civil Engineers. Martin Gardiner, C.E., City Engineer and Surveyor, Newcastle."

A few months later, on 2 January 1866, there was more self-promotion with the following, from a letter to the Empire:

From the report of the Deputy Surveyor-General on the state of the Survey department, I learn that he recommends the Government to send to England for a scientific trigonometrical and geodetic surveyor, and for an equally qualified draughtsman for the office-work pertaining to trigonometrical surveys.

Now, I can produce abundant testimony (to those who are sufficiently advanced in the science of the profession to be able to understand the worth of such testimony) as to my thorough qualifications to perform either the field or office duties of trigonometrical and geodetic (astronomical) surveying, and to avail myself of the formulae of reduction, \&c, contained in the most approved French and English authors, as Puissant Airy, and the published accounts of the ordinance survey of Britain and Ireland ... I maintain that at such work I have no superior in this colony, or in England ... I hope Mr. Adams will not overlook capable men who are now in the colony; and I would call his attention to the two following letters the first of which is from his friend Mr. Hodgkinson, the most scientific and accomplished professional surveyor in the service of the Victorian Government.

The reference in the last lines is to Clement Hodgkinson (1818-1893), a public servant and surveyor, heavily involved with the Philosophical Institute and then the Royal Society of Victoria. Gardiner's description of him is apt. ${ }^{12}$ His letter to Gardiner is dated

\footnotetext{
${ }^{11}$ See royalsoc.org.au/council-members-section/91-philsoc1856-65\#1866.

${ }^{12}$ Hodgkinson is described in Counting Australia In (p. 76) as the author of the "first paper of mathematical interest published in Victoria" (Hodgkinson [8]).
} 
9 June 1860 and reads as follows: "As you state that you are about to proceed to Sydney, with a view to employment as a railway surveyor, I beg to assure you that, in my humble opinion, your qualifications are of the very highest order. As a member of the Royal Society of Victoria, you have not only contributed to the transactions of that society some valuable information on professional subjects, but also, some papers displaying profound knowledge of the higher branches of mathematics and great originality and genius."

The other letter that Gardiner mentions was from Richard Townsend (1821-1884), an eminent geometer and professor of natural philosophy at Trinity College, Dublin. The letter, dated 17 October 1865, is highly praising of Gardiner's work. For example, referring to one of Gardiner's papers, he wrote: "I can assure you I have not for a long time enjoyed a greater treat or experienced more pleasure than its study has afforded me. You need not ask me, my dear sir, to help to rescue your papers from obscuritythat paper will immortalise your name and hand it down to history, as that of a pure geometer of the first order."

Townsend's letter is addressed to Gardiner at "St. John's College, Sydney". In Volume IV (1866) and from Volume VII (1867) to Volume XXXVI (1881), Gardiner was listed as a contributor to Mathematical Questions, with their Solutions, from the "Educational Times" and he described himself there (from Volume VIII onwards) as "late Professor of Mathematics in St. John's College, Sydney." There is no evidence, according to the archivist at St John's College in the University of Sydney (personal communication) of any such association. The title of professor would only have been allowed by the college if it had been bestowed by some other institution and there is no evidence of that, either. I have noticed only the following two contributions from Gardiner to Mathematical Questions: Unsolved Question No. 1882 in Volume VI (1866) and No. 2255 in Volume VII (1867). In contrast, for example, Sir James Cockle had numerous contributions in most volumes in this period.

As their titles suggest, these volumes consist largely of mathematical problems and their solutions from The Educational Times. ${ }^{13}$ In the occasional lists of contributors that the journal published (which were distinct from those in the Mathematical Questions) from 1870 to 1875, Gardiner was listed as "Martin Gardiner, F.R.A.S., St. John's College, Sydney, Australia." It is known (indirect personal communication) that Gardiner was not at any time a Fellow of the Royal Astronomical Society, and nothing else seems plausible. He did not use those initials in any other context.

Gardiner contributed four questions to The Educational Times: No. 1855 in Volume XVIII (December 1865); No. 1882 in Volume XVIII (January 1866) (repeated as No. 4056 in Volume XXVI (April 1873)); No. 1897 in Volume XVIII (February 1866) (repeated as No. 4106 in Volume XXVI (June 1873)); and No. 2255 in Volume XIX (October 1866). Nos 1882 and 2255 subsequently appeared with the same numbers in Mathematical Questions, as recorded above. No. 1882, slightly reworded and ascribed to "the Editor" rather than Gardiner, was solved by Âsûtosh Mukhopâdhyây in Volume XLIII (1885) of Mathematical Questions. I am grateful to Jim Tattersall for this information; he asserts further that Gardiner did not produce solutions for any of his questions.

Under the heading "FENIAN EXCITEMENT AT NEWCASTLE, N.S.W.", the Newcastle Chronicle on 28 March 1868 reported that Gardiner was before the Court, "on summons, to answer a charge of using insulting words to one Charles Edward Thurlow, on the 21st instant, whereby a breach of the peace might have been occasioned." $\mathrm{He}$

\footnotetext{
${ }^{13}$ Full title: The Educational Times and Journal of the College of Preceptors, "A Monthly Journal of Education, Literature and Science", published in London in varying forms from 1847 to 1923.
} 
pleaded not guilty. Not long before, on 12 March, there had been the attempted assassination in Sydney of Prince Alfred, Duke of Edinburgh, during the first ever royal visit to Australia. It was seen as an instance of the pervading tension between Irish Catholics and non-Catholics during what was termed "Fenian terrorism" in England. (The Fenians sought the establishment of an independent Irish republic.) Thurlow complained that, while walking with Gardiner and another man the previous Saturday, and having expressed the view that "the colony had been disgraced by the attempt", Gardiner had immediately replied, "The whole of you in the colonies are a set of cowards and toadies." Thurlow's response was "Gardiner, I'd rather be one of the cowards and toadies that you call the colonists than such an unhappy mortal as yourself; you are always grumbling, or abusing somebody or something." And so it continued, with Thurlow calling Gardiner a Fenian, among other things. The Bench considered the case to be "not a serious one", but "found the defendant guilty, and sentenced him to pay a fine of $20 \mathrm{~s}$. and $4 \mathrm{~s} .6 \mathrm{~d}$. court costs, in default of payment, to be imprisoned in the lock-up for forty-eight hours." The fine was paid.

Gardiner continued working in Newcastle until the end of 1868.

\section{Sydney again; City College}

Gardiner returned to Sydney. On 2 June 1869 he presented three papers to the monthly meeting of the Royal Society of New South Wales - papers (h), (i) and (j) in the Appendix. The meeting and details of all three papers were reported in a number of newspapers in the following week.

He then embarked on his most ambitious educational venture. With Sheridan Moore, he made extensive plans for the City College, to be situated near Hyde Park, Sydney, and to open on 19 July 1869. The College was to have two departments, a School of Engineering, Surveying, and Architecture; and a Classical, English, and Commercial School. The former was advertised as "exclusively under the charge and direction of Mr. Martin Gardiner, C.E., Queen's University, Ireland, Mem. of Math. Society of London". Here we have the first mention of Gardiner as a member of the London Mathematical Society. Elizabeth Fisher, the Membership \& Activities Officer there, has confirmed to me (personal communication) that Gardiner was elected as a member on 27 June 1867 and, at that meeting, "Prof. Hirst communicated a Paper 'On the determination of Double Entities in Uniquadric Homographics,' by Mr. Gardiner." I am grateful to Ms Fisher for bringing the paper to my attention; see Appendix (g).

Many of the advertisements included the college's prospectus, of which the following is a very small part.

Mr. Gardiner obtained the highest distinction in Mathematics, Natural Philosophy, and Civil Engineering, during his University career, and has since then been professionally engaged as draughtsman, land-surveyor, engineer and surveyor on railways and other works. His elementary mathematical and engineering papers have been published by the Royal Societies of Sydney and Melbourne, and his recent researches in the higher branches have had the honour of publication by "The Mathematical Society" and "The Royal Society," of London.

Accompanying references included Morris Birkbeck Pell (1827-1879), first professor of mathematics in the University of Sydney, Sir James Cockle, and "Professor Townsend, (Trinity College Dublin.) Professor Hirst, (London University). Professor Cayley, (University of Cambridge) President of the Mathematical Society of London."

The City College was first advertised on 12 June, five weeks before it was due to open, but within a month or so, before it had opened, there was an unexplained falling out between Gardiner and Moore. Many of the later advertisements did not mention Gardiner, and for the opening on 19 July there was again no mention. The opening 
was in fact postponed for a week because of "the inclement weather", according to a newspaper advertisement.

On 7 August there was a further advertisement in Freeman's Journal for the City College, along the lines of some of the earlier ones but with Gardiner's name absent. In The Sydney Morning Herald on the same day, and often over the next few weeks, Gardiner advertised his own services separately: "Gentlemen instructed in all branches of Mathematics, Surveying, and Engineering. Proficiency guaranteed to articled pupils." The split was fully apparent by 19 August with an advertisement in The Sydney Morning Herald announcing that the "entire course" in the School of Civil Engineering, Surveying, and Architecture, of the City College, had been "re-constructed" under the direction of "EDWARD HUGHES, Esq., C.E., late Resident Engineer on the Punjaub Railways, formerly (for four years) Assistant Engineer on Brassey and Co.'s French Railway Contracts, Messrs. Grissell's Contracts, Great Yarmouth Bridge Works, Roads, \&c."

Then the scheme collapsed entirely, and it cannot be claimed that it would have succeeded with Gardiner remaining as one of the headmasters.

Throughout this time, Gardiner's researches in geometry continued. The monthly meeting of the Royal Society of New South Wales for October 1869 was reported on as follows by The Sydney Morning Herald: "Mr. Martin Gardiner, C.E., then read to the members of the Royal Society a paper on 'Improved Solutions to Important Problems in Trigonometrical Surveying.' Mr. Gardiner demonstrated the principles he contended for in the paper by means of diagrams, and was listened to with great attention by all present. The subject treated of was evidently much appreciated, but was of rather too abstruse a character to be made intelligible in a popular form."

At the end of that year, 1869, the Borough of Balmain in Sydney announced Gardiner's appointment as Council Clerk and Surveyor, but the following August saw him declared insolvent and he was obliged to resign from his position.

\section{Otago Chair; Divorce}

The University of Otago in Dunedin, New Zealand, the country's first university, was established in 1869, and Gardiner was an applicant for the chair of Mathematics and Natural Philosophy. I have copies of four letters that he wrote to the University Council over the period 27 May to 31 August 1870. Garry Tee from the University of Auckland received these from David Murray, a university archivist in Otago, and forwarded them on, and I am grateful to both for this. The four letters are written from "Darling Street, Balmain", and in one, dated 18 June, there is the following remarkable passage.

I think it proper, under present circumstances, to observe that the Professors of Mathematics \& Natural Philosophy in the Sydney \& Melbourne Universities have contributed nothing theoretical or practical to science in these colonies, or elsewhere, since their arrivals, nor, as a natural consequence, have the graduates or scholars done anything to give the universities a name or to prove them to be successful institutions.

To set the record straight, if that is required, Pell from Sydney University was "regarded as the most important commentator on mortality in Australia before 1900" (Lancaster [9]), and Wilson, a fervent astronomer, was instrumental in bringing what became known as the Great Melbourne Telescope to Australia in 1869 ([2], p. 56).

Two references accompanied Gardiner's application and they are worth reproducing in full. The first was from William Hearn at the University of Melbourne, dated 2 May 1870 .

Mr. Martin Gardiner, C.E., was a student in Queen's College, Galway, when I was connected with that institution. Mr. Gardiner, obtained the highest distinctions in the College, in its 
engineering department (including the higher branches of Mathematics and Physics) and subsequently obtained the diploma of Civil Engineer.

I subsequently knew Mr. Gardiner in Victoria, when he was a member of the Royal Society. He pursued, often in circumstances of great difficulty and discouragement, his mathematical studies with great success.

I do not consider myself competent to express an opinion on the value of Mr. Gardiner's papers, but from my general knowledge of his powers if he were able to devote his whole time without interruption to his favourite pursuits, he would be speedily known as one of the most successful Mathematicians of the day.

The other was from Sir James Cockle in Brisbane, dated 4 May 1870.

I have to beg you to accept my apologies for not having written to you long since. Your letter dated April 21st, 1870 informs me that you are a candidate for the Professorship of Mathematics and Natural Philosophy in the University of Otago, New Zealand.

It would give me pleasure to hear that you had succeeded in obtaining the appointment.

From papers which you have sent me long since, and from a more recent one by you which I have seen in (I think) "The Quarterly Journal of Mathematics," I believe you have been and to be an able and persevering investigator in an abstruse and difficult portion of Mathematical Science. And in the fact of your having pursued these advanced studies, I find an ample warrant for sending you this testimonial accompanied by my best wishes for your success in your application, and that in such an appointment you may find a fitting and agreeable field for the exercise of your Mathematical talents.

The letters appear in the collected correspondence of Sir Henry Parkes. ${ }^{14}$ With these is the letter from Clement Hodgkinson that we have seen before, but bearing the date "January 1860" rather than 9 June 1860 as before, and with a few other minor differences. ${ }^{15}$ There is also a letter from T. Archer Hirst of University College, London, dated 1 January 1867, commending Gardiner's memoir, "Researches in the Geometry of Three Dimensions".

There were 62 applicants for the position in Otago, including nine specified as "From the Colonies". Success went to a Scot, John Shand, who is remembered in New Zealand mainly for his support for teaching and secondary education.

Two and a half years later, apparently living the whole while in Sydney, Gardiner was again granted an "insolvent's certificate", ${ }^{16}$ and later that year he issued a notice: "I will not be responsible for any Debts contracted by any person whomsoever without my own authority. Martin Gardiner, C. E.". ${ }^{17}$

For Gardiner's wife Emma, it was much worse than financial hardship. On 22 October 1872, the Evening News reported that, in the Central Police Court, "Martin Gardiner was fined 40s, with 6s 6d costs of court and 21s professional costs, or seven days, for assaulting Emma Gardiner." Three days later, in the The Sydney Morning Herald, we find: "In Emma Gardiner v. Martin Gardiner, an order was made by consent of defendant for a weekly payment of 30s for the separate maintenance of his deserted wife." Two years later, Gardiner was on another charge before the Central Police Court for "assaulting and beating his wife Emma Gardiner." It was another nineteen years, December 1893, before Emma "commenced a suit" against Martin Gardiner for divorce on the ground of desertion. ${ }^{18}$ In an appearance before the Supreme Court, she asserted that Gardiner "had deserted her since 1874, and that she had never heard from or of him from that date." The presiding Justice granted the decree nisi, to be made absolute after three months.

\footnotetext{
${ }^{14}$ Parkes, op. cit.

${ }^{15}$ Such letters would, of course, have been reprinted by the recipient for subsequent distribution, and might well be altered in content.

${ }^{16}$ Empire, 2 April 1873.

${ }^{17}$ The Sydney Morning Herald, 23 September 1873.

${ }^{18}$ NSW Government Gazette, 8 December 1893, p. 9285.
} 


\section{FINAL WANDERINGS}

In fact, in 1874 Gardiner was in Brisbane, as evidenced by the following letter from Sir James Cockle to his equivalent Chief Justice in New South Wales, Sir Alfred Stephen, seeking Stephen's help to find employment for Gardiner.

There is living in New South Wales, I believe in Sydney, Mr. Martin Gardiner, C.E. If it should happen to come in your way to be able to render him a service I think that such favour would be well bestowed. He is a mathematician of a very high order. It was only a day or two ago that I met with his name in an English mathematical publication and in connection not with an isolated problem, but with a recondite class of researches. I believe that he has contributed at least two papers to the Transactions of New South Wales. He is not however a theorist alone, but he is a practical man and visited Queensland lately in quest of professional employment. There was however no opening for him there and I failed in an effort I made for him. I then thought of some endeavor to interest the New South Wales officials in his behalf, but I gathered from what he said that he thought that your good word or influence would be more powerful ... Accordingly after some delay, caused in part by pressures of business, I write. And I do so because the picture of such a man as Mr. Martin Gardiner working hard for inadequate remuneration is one of the most striking instances that I know of how occasionally cruel Fortune is in her caprices. With but a fair chance I doubt not that he would make his mark in the world. ${ }^{19}$

Soon after, Gardiner was back in Melbourne. In May 1876, he presented to the Royal Society a paper on geodetic surveying, but "as, owing to its length, it would have taken several hours to read, Mr. Gardiner gave a précis of the contents of the paper, which he explained by diagrams." ${ }^{20}$

In Queensland again, a year or two later, there are some minor newspaper references suggesting that Gardiner worked as a surveyor until the middle of 1883. During 1883 and 1884, preliminary surveys were being undertaken for the famous Cairns Range Railway to Kuranda and Gardiner is listed as one "of the various officers who were directly responsible for the survey of and the building of the Range Railway." So is his son Charles Napoleon, who was also a licensed surveyor (Collinson [4]). The first section of the railway was completed in October 1887, but Gardiner was long gone from Queensland by then. He had travelled to Adelaide where he was noted as presenting to the South Australian Institute of Surveyors his works on "Practical Geodesy" and "Dynamics". ${ }^{21}$ Soon after, he opened a "School of Civil Engineering and Surveying, and of Pure and Applied Mathematics". Advertisements for his new school appeared regularly until 30 August, and then no more was heard of the school, or of Gardiner in South Australia.

In the early 1890s, Gardiner was in Melbourne yet again. There was an advertisement in The Argus for "ELEMENTARY ORGANIC GEOMETRY (Preparatory to Quaternions), By Martin Gardiner, C.E., Member of the London Mathematical Society." ${ }^{22}$ I cannot find any other mention of this book. On 10 March, according to The Age, he attended the Annual General Meeting of the Royal Society of Victoria and presented a paper there. The paper's title is not given in The Age, but it was presumably Appendix (v), his last mathematical publication.

The final newspaper references to Gardiner are from Perth, Western Australia. From The West Australian (18 April 1898), and similarly in other papers there in the following

\footnotetext{
${ }^{19}$ Correspondence from Sir James Cockle to Sir Alfred Stephen (23 December 1874) in "Public Men of Australia", call no. MS C4872 (State Library of NSW), pp. 202-205. I am grateful to Jim Tattersall for bringing this item to my attention.

${ }^{20}$ The Argus, 12 May 1876.

${ }^{21}$ South Australian Register and The South Australian Advertiser, 17 July 1884.

${ }^{22}$ The Argus, 17 January 1891.
} 
days, we find that Gardiner was employed teaching elementary engineering in "the James-street Central School" and was again advertising classes of his own. ${ }^{23}$

That is all. As to Gardiner's death, the only possibility that has been found is in the West Australian Registry. A Martin Gardiner, engineer, died on 3 April 1899 at Helena Weir, Mundaring, about 50km east of Perth. His age at death is given as 60, which does not accord with being born in 1832 or 1833 , but may be a common error of the times.

\section{Other IRISh-Australian mathematicians}

The second such, after Martin Gardiner, was Henry Charles Kingsmill (1843-1909). He was born in Donegal, studied in Cambridge, and came to Australia in 1873. Kingsmill was instrumental in the formation of the University of Tasmania and held lecturing positions there in mathematics and surveying.

John Henry MacFarland (1851-1935) was also prominent in university administration, becoming chancellor of the University of Melbourne in 1918. He was born in Omagh, County Tyrone, and studied mathematics at Queen's College, Belfast, and then St John's College, Cambridge. MacFarland first went to the University of Melbourne, as Master of Ormond College, in 1881. He was knighted in 1919.

Then there was John Frederick Adair (1852-1913), from Dublin, who studied at Trinity College, Dublin, and then Pembroke College, Cambridge. He vied with Thomas Lyle (below) and William Henry Bragg to succeed Horace Lamb as Elder Professor of Mathematics in the University of Adelaide. (Bragg won, and was the winner in 1915 of the Nobel Prize in Physics, jointly with his son.) Adair won some fame as a cricketer playing for Ireland in 1883, before taking a demonstratorship in physics at the University of Sydney for three years.

Much better-known than these was Thomas Ranken Lyle (1860-1944), born in Coleraine. After distinguished study at Trinity College, Dublin, he came to Australia in 1889 as professor of natural philosophy in the University of Melbourne. He retired from that position in 1915 because of latent injuries received playing rugby for Ireland before going to Australia. Lyle was made a fellow of the Royal Society in 1912 and he gained a knighthood in 1922 .

Hugh Davison Erwin (1879-1957), with a BA, BSc from the Royal University of Ireland, was, like Kingsmill, also involved with mathematics at the University of Tasmania.

There are no others, closely associated with Ireland and then actively associated with Australian mathematics, who are known to me up to the appointment of Vincent Hart to the University of Queensland in 1964. Hart was born in Hull, Yorkshire, in 1930 and moved to Cork in 1940.

All of these, except MacFarland, are discussed in some detail in Counting Australia In. See also Mulcahy [11] for an interview with Vincent Hart. I apologise for not having a comprehensive knowledge of others who would be more recent arrivals in Australia.

\section{APPENDIX}

The following are all the papers and pamphlets (and a book that never saw the light of day) by Martin Gardiner that I am aware of. These were listed in Counting Australia In ([2], pp. 387-388), except for (d), (f), (o) and (q), which were included in [3]. The titles of the "four papers" in (e) were not given in the former list.

(a) Geometrical Papers by Martin Gardiner C.E., State Library of Victoria, Australian Manuscripts Collection (MS 9947, MSB125) (1857).

${ }^{23}$ The West Australian, 6 June 1898. 
(b) Improvements in fundamental ideas and elementary theorems of geometry, Trans. Phil. Inst. Vic. (4) (1859), 76-96. Also published as a reprint by Mason and Firth, Melbourne (1859), 24 pages.

(c) The "three sections," the "tangencies," and a "loci problem" of Apollonius, and porismatic developments, Trans. Roy. Soc. Vic., (5) (1860), 19-89. Also published as a reprint by Mason and Firth, Melbourne (1860), 73 pages.

(d) A paper concerning polygons inscribed in curves and surfaces of the second degree, Quart. J. Pure Appl. Math., (7) (1866), 146-154, 284-301. With regard to this paper, Richard Townsend wrote, "A very elegant construction, at once simple, direct, and general, has recently been given for the case of $n$ odd, by Mr. M. Gardiner, C.E., late Scholar of Queen's College, Galway, Ireland, and since Professor of Mathematics in St. John's College, Sydney, New South Wales." (See the footnote in Townsend [13].) Elizabeth Fisher of the London Mathematical Society informed me of this.

(e) "Geometrical Researches" in four papers, comprising numerous new theorems and porisms, and complete solutions to celebrated problems. 1. Researches concerning figures particularly derived from other figures, 2. Researches concerning n'gons inscribed in other n'gons, 3. Researches concerning n'gons inscribed in curves of the second degree, 4. Researches concerning n'gons inscribed in surfaces of the second degree, Trans. Phil. Soc. NSW, (1862-1865) (1866), 61-126.

(f) On the inscription, by a simplification of Sir W. R. Hamilton's process of reduction, of closed n-gons in any quadric, so that the sides of each shall pass in order through $n$ given points, Proc. Lond. Math. Soc., (s1-2) (1866), 63-69.

(g) Memoir on "Undevelopable uniquadric homographics", Proc. Roy. Soc. Lond., (16) (1867-68), 389-398.

(h) Analytical solution to Sir William Hamilton's problem on the inscription of closed N'gons in any quadric, Trans. Roy. Soc. NSW, (3) (1869), 38-41.

(i) Important new theorem in the geometry of three dimensions, Trans. Roy. Soc. NSW, (3) (1869), 41-42.

(j) An exposition of the American method of levelling for sections - its superiority to the English and French methods as regards actual field practice and subsequent plotting of the section, Trans. Roy. Soc. NSW, (3) (1869), 43-45.

(k) Improved solutions to important problems in trigonometrical surveying, Trans. Roy. Soc. NSW, (3) (1869), 129-133.

(1) Properties of quadrics having common intersection, and of quadrics inscribed in the same developable, (being an extension of Chapter XVI. of Chasles' Conics), Quart. J. Pure Appl. Math., (10) (1870), 132-147.

(m) On the solution of certain geodesic problems, Trans. Roy. Soc. NSW, (7) (1873), $53-72$.

(n) On geodesic investigations, Trans. Roy. Soc. NSW (7) (1873), 149-182.

(o) Leichhardt (cartographic material) (1874). A ms. map, 54 x $130 \mathrm{~cm}$, held by the State Library of NSW.

(p) On practical geodesy, Trans. Proc. Roy. Soc. Vic., (13) (1878), 1-66.

(q) Disproof of the "Parallelogram of Rotative Velocities", The Week (Brisbane), (2 June 1883), 21.24

(r) Solution to the celebrated fundamental question (hitherto unsolved) of dynamics, Woodcock and Co., Brisbane (1883), 10 pages. This booklet was noted as received by the Royal Society of Queensland as its first "donation", Proc. Roy. Soc. Queensland, (1) (1884), 1.

${ }^{24}$ The argument is invalid, according to physicists I have consulted. 
(s) Solution to one of the most celebrated fundamental questions (hitherto unsolved) in dynamics, Woodcock and Co., Brisbane (July 1883), 8 pages.

(t) Determination of the motion of the solar system in fixed unalterable space, Woodcock and Co., Brisbane (1883), 14 pages.

(u) Elementary organic geometry (preparatory to quaternions). Described as "Ready for Publication", The Argus (17 January 1891). Unseen; no other references.

(v) On "confocal quadrics of moments in inertia" pertaining to all planes in space, and loci and envelopes of straight lines whose "moments of inertia" are constant, Proc. Roy. Soc. Vic., (5) (1893), 200-208.

\section{REFERENCES}

[1] J. M. Bennett: Sir James Cockle, First Chief Justice of Queensland, Queensland Heritage (2) (1972), 3-12.

[2] G. Cohen: Counting Australia In: The People, Organisations and Institutions of Australian Mathematics, Australian Mathematical Society / Halstead Press, Canberra (2006).

[3] G. L. Cohen: A Bibliography of Australian Mathematics to 1960 with Observations Relating to the History of Australian Mathematics, Historical Records of Australian Science (31) (2020), 17-25.

[4] J. W. Collinson: Building the Cairns Range Railway, J. Royal Historical Society of Queensland (5) (1954), 1069-1075.

[5] T. S. Davies: Historical notices respecting an ancient problem, in W. Rutherford and S. Fenwick (eds) The Mathematician (3) (1850), 75-87.

[6] M. A. B. Deakin: Sir James Cockle, FRS, Austral. Math. Soc. Gaz. (29) (2002), 7-12.

[7] F. D. Glass: Moore, Joseph Sheridan (1828-1891), Australian Dictionary of Biography, National Centre of Biography, Australian National University, http://adb.anu.edu.au/biography/moorejoseph-sheridan-4234/text6831, published first in hardcopy 1974, accessed online 16 January 2020.

[8] C. Hodgkinson: Original rules and tables, adapted to cases of sidelong ground in the setting-out and computation of railway earthworks, Trans. Phil. Soc. Vic. (1855), 74-84.

[9] H. O. Lancaster: Morris Birkbeck Pell, 1827-1879, Austral. Math. Soc. Gaz. (4) (1977), 89-94.

[10] J. Mitchell: Queen's College, Galway 1845-1858: From Site to Structure, Journal of the Galway Archaeological and Historical Society (50) (1998), 49-89; retrieved 30 January 2020, from www.jstor.org/stable/25550196.

[11] C. Mulcahy: An interview with Vincent Hart, Irish Math. Soc. Bull. (79) (2017), 43-52.

[12] E. C. Rowland: The story of the New South Wales railways, Royal Australian Historical Society, Journal and Proceedings, (40) (1954), 245-286.

[13] R. Townsend: Solution, by the method of ordinary homographic division, of the problem, "To inscribe in a given ruled quadric a polygon of any given order whose sides shall pass in any prescribed order of sequence through an arbitrary system of given points in space", Proc. Lond. Math. Soc. (s1-2) (1866), 21-26.

Graeme Cohen retired as an associate professor in the School of Mathematical Sciences, University of Technology Sydney, in 2002. His research interests were in elementary number theory and applications of mathematics to sport. On retirement, he undertook the writing of the history of Australian mathematics to help commemorate the 50th anniversary of the founding of the Australian Mathematical Society in 1956. This led to further work in that area.

Formerly, School of Mathematical Sciences, University of Technology Sydney, New South Wales, Australia

E-mail address: g.cohen@bigpond.net.au 